\title{
Stabilisation of $\mathrm{Pb}$ in Pb Smelting Slag-Contaminated Soil by Compost-Modified Biochars and Their Effects on Maize Plant Growth
}

\author{
Mary B. Ogundiran ${ }^{*}$, Olamide 0. Lawal ${ }^{1}$, Sifau A. Adejumo² \\ ${ }^{1}$ Analytical/Environmental Unit, Department of Chemistry, University of Ibadan, Ibadan, Nigeria \\ ${ }^{2}$ Department of Crop Protection and Environmental Biology, University of Ibadan, Ibadan, Nigeria \\ Email: ${ }^{*}$ mbogundiran@yahoo.com
}

Received 29 June 2015; accepted 31 July 2015; published 3 August 2015

Copyright (C) 2015 by authors and Scientific Research Publishing Inc.

This work is licensed under the Creative Commons Attribution International License (CC BY). http://creativecommons.org/licenses/by/4.0/

(c) (i) Open Access

\section{Abstract}

Compost has been used to stabilise lead $(\mathrm{Pb})$ in soil. However, compost contains a high level of dissolved organic matter (DOM) which may make Pb bioavailable in plant and thereby limiting its effectiveness and application. Addition of biochar to compost can reduce this effect. Rice husk (RH) and Cashew nut shell (CNS) biochars and compost-modified biochars were used in comparison to compost for stabilizing $\mathrm{Pb}$ in lead smelting slag (LSS)-contaminated soil $(\mathrm{Pb}=18,300 \mathrm{mg} / \mathrm{kg})$ in Nigeria. Efficiency of $\mathrm{Pb}$ stabilisation in control and amended soils was assessed using $\mathrm{CaCl}_{2}$ batch leaching experiment and plant performance. In pot experiments, maize plant was grown on the contaminated soil and on soil treated with minimum and optimum doses of the amendments singly and in combination for 6 weeks. Agronomical and chemical parameters of the plants were measured. $\mathrm{CaCl}_{2}$-extractable $\mathrm{Pb}$ in the untreated soil was reduced from $60 \mathrm{mg} / \mathrm{kg}$ to $0.55 \mathrm{mg} / \mathrm{kg}$ in RHB amended soils and non-detectable in other amended soils. RH-biochar/compost increased plant height, number of leaf and leaf area more than the others. Similarly, at minimum rate, it reduced root and shoot $\mathrm{Pb}$ by $\mathbf{9 1 \%}$ and $\mathbf{8 6 . 0 \%}$ respectively. Compost-modified rice husk biocharstabilised $\mathrm{Pb}$ in lead smelting slag contaminated soil reduced $\mathrm{Pb}$ plant uptake and improved plant growth. Lead stabilisation through the use of rice husk biochar with compost may be a green method for remediation of lead smelting slag-contaminated soil.

\section{Keywords}

Biochar, Compost-Modified Biochar, Lead Smelting Slag, Lead Stabilisation

\footnotetext{
${ }^{*}$ Corresponding author.
}

How to cite this paper: Ogundiran, M.B., Lawal, O.O. and Adejumo, S.A. (2015) Stabilisation of Pb in Pb Smelting Slag-Contaminated Soil by Compost-Modified Biochars and Their Effects on Maize Plant Growth. Journal of Environmental Protection, 6, 771-780. http://dx.doi.org/10.4236/jep.2015.68070 


\section{Introduction}

A high concentration of lead in soil that is contaminated by lead slag is dangerous to man and the ecosystem. The level of $\mathrm{Pb}$ above background concentrations in soil affects soil fertility, plant and animal health. High levels of $\mathrm{Pb}$ in soil can alter biomass of soil microbes and their activities in nutrient recycling. They can also cause plant physiological disturbances such as oxidative stress and reduction in plant yield [1]. Furthermore, a high concentration of $\mathrm{Pb}$ in soil is capable of migrating to other environmental media such as air and water bodies where it equally becomes poisonous to living organisms. Lead accumulation in human systems has been associated with neurological, reproductive, developmental, metabolic and behavioral changes [2].

There are reports of soil contamination with $\mathrm{Pb}$ in many parts of the world that are known with mining and lead-acid battery recycling activities [3]-[5]. To circumvent bioavailability of $\mathrm{Pb}$ in contaminated soil, various methods of soil remediation have been employed. The commonly utilised methods include containment, biological treatments, in situ solidification/stabilisation and immobilisation [6] [7]. However, organic wastes (such as compost and biochar) stabilisation of heavy metals in contaminated soil is gaining ground over the conventional technologies [8]-[12]. This is because compost and biochar have strong binding power for heavy metals and have potentials to improve soil conditioning properties for plant growth [8] [12].

Studies have shown that remediation of Pb-impacted soil using compost stabilizes heavy metals, restores soil fertility and promots plant health on the remediated soils [8]-[10]. Biocharremediation of heavy metal-contaminated soil is an emerging soil reclamation method which employs biological residues combusted under low oxygen conditions, resulting in a porous, low density carbon rich material to decontaminate polluted soil [12]. Biochar contains high CEC which can retain essential plant macronutrients such as $\mathrm{Ca}, \mathrm{Mg}$ and $\mathrm{K}$ in soil. Stabilisation of heavy metals in soil may occur via complexation due to alkaline $\mathrm{pH}$ and surface organic functional groups of biochar [13]. It has been documented that biochar amendment improves soil physico-chemical properties such as particle size distribution, water holding capacity, soil organic carbon, $\mathrm{pH}$, CEC, soil biological activities, and plant growth in addition to stabilisation of heavy metals in soil [12] [14]. Additionally, unlike compost, biochar has the characteristic potential to remain long in soils with reduced bio-decomposition [15]. However, the energy required for pyrolysis of biochar production may an issue to be considered. Remediation technology that combines compost and biochar will be more environmentally-friendly and less expensive in terms of reduction in fast decomposition of compost and energy required to produce biochar.

Previous research on heavy metals stabilisation in soil by organic wastes was mainly with the use of compost [9] [10] and biochar of different types [12]. But, not much information is available on the synergistic use of compost, rice husk and cashew nut biochars as amendments for heavy metals stabilisation in contaminated soils. Therefore, this study was designed to investigate the efficacy of compost (C), rice husk biochar (RHB), cashew nut shell (CNSB) biochar and compost-modified biochars (CNSBC and RHBC) to stabilize Pb in lead smelting slag (LSS)-contaminated soil in Nigeria. The effectiveness was measured using $\mathrm{CaCl}_{2}$ batch leaching experiment, yield and $\mathrm{Pb}$ uptake by maize plant.

\section{Materials and Method}

\subsection{Soil Collection}

The soil sample for this study was randomly collected from an abandoned lead smelting slag contaminated site in Ibadan, Nigeria. The site lies between longitude $7^{\circ} 24^{\prime} \mathrm{N}$ and latitude $4^{\circ} 00^{\prime} \mathrm{E}$ at an elevation of $174 \mathrm{~m}$ above sea level. The large expanse of agricultural land in this area has been made unproductive due to the impact of the LSS illegally dumped on the land several years ago. Soils were sampled at different points at $15 \mathrm{~cm}$ depth and mixed to form composite sample which was transported to the laboratory.

\subsection{Amendments Preparation}

The biochars were produced from rice husk and cashew nut shell. These agricultural residues were chosen due to their abundance in Nigeria and in other places in the world. Their use as biochar sources will minimise the problem of managing their waste. Compost was prepared from wild sunflower (Tithoniadiversifolia) and poultry liter in ratio 3:1 of sunflower to poultry manure for 12 weeks [9]. The different agricultural residues (rice husk and cashew nut shell) collected were pyrolysed locally in the presence of low oxygen using a simple, low cost two barrel charcoal retort method [16] at approximate pyrolysis temperature between $450^{\circ} \mathrm{C}$ and $500^{\circ} \mathrm{C}$ ). The 
produced chars were ground to fine powder and sieved through a $2 \mathrm{~mm}$ sieve.

\subsection{Soil Physico-Chemical Characterization}

The soil samples were air-dried at room temperature for two weeks, mechanically ground and sieved to $<2 \mathrm{~mm}$. The $<2 \mathrm{~mm}$ fraction soil samples were analysed for physicochemical parameters. Organic carbon was determined using potassium dichromate method [17]. $\mathrm{pH}$ was measured in water at soil: water ratio of 1:1 using $\mathrm{pH}$ meter. Particle size analysis was determined by hydrometer method. To determine the total environmentally available Pbconcentrations in the soil and amendments, one gramme of soil was acid digested with $10 \mathrm{~mL} 2 \mathrm{M}$ $\mathrm{HNO}_{3}$ for 2 hours at $90^{\circ} \mathrm{C}-100^{\circ} \mathrm{C}$ [5]. In order to solubilise the minerals in the biochars and compost, there is need to destroy the organic matter contents. To achieve this, one gramme each of biochars and compost was ashed in a muffle furnace for 6 hours at a temperature between $450^{\circ} \mathrm{C}-500^{\circ} \mathrm{C}$. The ash was dissolved in $10 \mathrm{~mL}$ of $2 \mathrm{M} \mathrm{HNO}_{3}$, filtered with Whatman filter paper No. $2(8 \mu \mathrm{m})$ and made up to mark in $25 \mathrm{~mL}$ volumetric flask [18]. The total environmentally available $\mathrm{Pb}$ concentration in soil and amendments digests was determined by atomic absorption spectrophotometer (Buck scientific model 210A) with air-acetylene flame. Exchangeable cations (Ca, Mg, Na, K) were extracted using 0.2 M Silver thiourea solution [19]. Potassium and Na were determined with a flame photometer (Jenway, PFP7) while Ca and Mg were measured using atomic absorption spectrophotometer. The cation exchange capacity was determined by the sum of the exchangeable bases including $\mathrm{Ca}, \mathrm{Mg}, \mathrm{K}$ and $\mathrm{Na}$ [20]. Kjedahl's method was used to determine nitrogen content [21]. Phosphorus was determined by Mehlich III method [22]. Two grammes ( $2.0 \mathrm{~g})$ of air-dried soil sieved to pass through $<2 \mathrm{~mm}$ were extracted with $20 \mathrm{~mL}$ of Mehlich-3 extracting solution [0.2 M Glacial acetic acid $\left(\mathrm{CH}_{3} \mathrm{COOH}\right), 0.25 \mathrm{M}$ Ammonium nitrate $\left(\mathrm{NH}_{4} \mathrm{NO}_{3}\right), 0.015 \mathrm{M}$ Ammonium fluoride $\left(\mathrm{NH}_{4} \mathrm{~F}\right), 0.013 \mathrm{M}$ Nitric acid $\left(\mathrm{HNO}_{3}\right), 0.001 \mathrm{M}$ ethylene diamine tetraacetic acid (EDTA) at $\mathrm{pH}=2.5 \pm 0.05$ ] on a mechanical shaker at $120 \mathrm{rpm}$ for 5 minutes. The suspension was filtered using Whatman filter paper No. 2. The phosphorus content was determined colorimetrically by molybdenum blue ascorbic acid method. The results of physicochemical properties of the soil, biochars and compost are reported in Table 1.

\subsection{Optimisation Experiment}

$0.01 \mathrm{M} \mathrm{CaCl}_{2}$ batch leaching experiment was conducted to optimize $\mathrm{Pb}$ stabilisation potentials of biochars,

Table 1. Physicochemical parameters of soil, biochars and compost.

\begin{tabular}{|c|c|c|c|c|}
\hline \multirow[t]{2}{*}{ Parameters } & \multirow[t]{2}{*}{ Contaminated soil } & \multicolumn{2}{|c|}{ Biochars } & \multirow[t]{2}{*}{ Compost } \\
\hline & & Rice husk & Cashew nut shell & \\
\hline $\mathrm{pH}$ & 5.70 & 7.40 & 6.30 & 8.70 \\
\hline TOC & 1.80 & - & - & - \\
\hline Sand (\%) & 43 & - & - & - \\
\hline Silt (\%) & 59 & - & - & - \\
\hline Clay (\%) & 9 & - & - & - \\
\hline $\mathrm{N}(\mathrm{mg} / \mathrm{kg})$ & 600 & 13,200 & 23,000 & 9600 \\
\hline Ca (mg/kg) & 213 & 9780 & 5340 & 29,000 \\
\hline Mg (mg/kg) & 86 & 3530 & 135 & 4540 \\
\hline $\mathrm{P}(\mathrm{mg} / \mathrm{kg})$ & 71.5 & 197 & 107 & 2090 \\
\hline $\mathrm{K}(\mathrm{cmol} / \mathrm{kg})$ & 0.46 & 12.4 & 2.80 & 21.9 \\
\hline CEC $(\mathrm{cmol} / \mathrm{kg})$ & 4.62 & 110 & 36.9 & 210 \\
\hline $\mathrm{Pb}$ (mg/kg) & 18,300 & 0.90 & 1.20 & 1.50 \\
\hline
\end{tabular}

-Not available, TOC—-Total organic carbon content, CEC-Cation exchange capacity. 
compost and compost-modified biochars in terms of the amount added to the contaminated soil. $0.0 \mathrm{~g}$ (contaminated soil without amendment), $0.05 \mathrm{~g}, 0.1 \mathrm{~g}, 0.2 \mathrm{~g}, 0.4 \mathrm{~g}$ of each biochar and compost was added singly and in combination with compost to $1.00 \mathrm{~g}$ of contaminated soil in $50 \mathrm{~mL}$ polycarbonate centrifuge tube. $5 \mathrm{~mL}$ of 0.01 $\mathrm{M} \mathrm{CaCl}_{2}$ solution was added and the solution was shaken for 2 hrs at $160 \mathrm{rpm}$ using an orbital shaker, after which the solution was filtered using Whatman filter paper No. 2. The filtrates were analysed for Pb concentration using atomic absorption spectrophotometer (Buck scientific model 210A). The percent stabilisation efficiencies of the amendments were calculated.

\subsection{Greenhouse Experiment}

Pot experiment was set up in a greenhouse to study the effect of biochars and compost both singly and in combination (equal proportion by weight using the minimum dose) on soil Pb stabilisation, maize plant growth and $\mathrm{Pb}$ accumulation. For comparison, the most effective dose $(0.4 \mathrm{~g})$ and the minimum dose $(0.05 \mathrm{~g})$ of the amendments from the batch leaching test were selected for the pot experiment. The amount of biochars and compost required were calculated with regards to the amount of soil used for planting (500 g) based on the results of the optimisation. This was equivalent to $25 \mathrm{~g}$ (50 g for combination) and $200 \mathrm{~g}$ of amendment per $500 \mathrm{~g}$ of soil to represent 0.05 and $0.4 \mathrm{~g}$ amendment/g soil rates respectively. Altogether there were 9 treatments and each treatment was performed in duplicate, giving a total of 18 bags. No extra macronutrient treatment from external source was applied to the soils.

The amendments were thoroughly mixed with the soils and transferred into $30 \mathrm{~cm}$ diameter polyethylene bags. Each bag was placed in a plastic bowl to prevent loss of leachate from the system and water was applied to each bag until soil reached $70 \%$ water holding capacity after which they were allowed to equilibrate for one week. During the period of one week the bags were watered every two days (approximately 100 - $200 \mathrm{~mL}$ ). After one week, the soil was sown with two maize seeds but the survival of the seedlings to the end of the experiments was dependent on the type and rates of the amendments. Watering of the plants was done at two days intervals. The leachate collected in each saucer was also returned to the experimental soil when necessary to prevent loss of the metal. At six weeks of planting, agronomical parameters such as plant height, number of leaves and leaf area were taken. After 6 weeks, plants were harvested. The roots of the maize plants were washed with distilled water to remove soil, the plant were separated into shoot and root and oven-dried for 3 days at $80^{\circ} \mathrm{C}$. The dry biomass was determined. After biomass determination, the oven-dried plant parts were ground. Depending on the root dry weight of the plant $\leq 1.00 \mathrm{~g}$ of each was ashed in a muffle furnace for 6 hours at a temperature between $450^{\circ} \mathrm{C}-500^{\circ} \mathrm{C}$ for $\mathrm{Pb}$ determination [18]. The experimental soils were also analysed for the total environmentally available $\mathrm{Pb}$ [5]. Data were analysed using descriptive statistics.

\section{Results and Discussion}

\subsection{Physico-Chemical Characteristics of Soil and the Amendments}

The physico-chemical properties of the soil, biochars and compost are Table 1 presents. The pH of unamended soil was 5.7 which showed that the soil was acidic.

The pH of CNSB is slightly acidic (6.30) compared to the $\mathrm{pH}$ of rice RHB and compost which are alkaline. The acidic $\mathrm{pH}$ of CNSB can be attributed to its anacardic acids content [23]. The organic carbon of the soil was as low as $1.80 \%$, which could be attributed to the high content of the slag which prevented vegetation of the soil. The concentration of $\mathrm{Pb}$ in the untreated soil was 18,300 mg/kg. Compost, RHB and CNSB have low Pb contents of $1.50,0.90$ and $1.2 \mathrm{mg} / \mathrm{kg}$ respectively, suggesting that there is no considerable contribution of $\mathrm{Pb}$ level when these materials are applied to the soil. The biochars and compost have high levels of Ca, Mg, N, P, K and CEC which was expected to improve the soil condition and enhance plant growth on application. The physicochemical parameters present the proposed amendments as non-hazardous, as potential soil nutrients sources and as heavy metal stabilisers.

\subsection{Effect of Amendment Dose on $0.01 \mathrm{M} \mathrm{CaCl}_{2}$ Extractable Pb}

The control and the amended soils at the different doses were subjected to $0.01 \mathrm{M} \mathrm{CaCl}_{2}$ solution extraction to determine extractable $\mathrm{Pb}$. The extractable $\mathrm{Pb}$ was highly dependent on the dose and the amendment type. The results are summarized in Figure 1. 


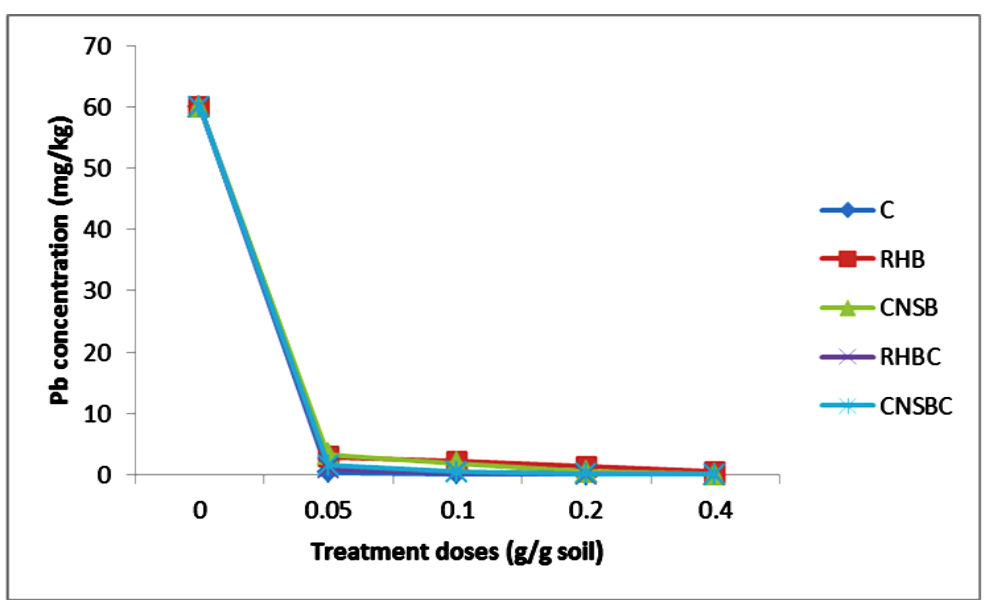

Figure 1. $\mathrm{Pb}$ concentrations extracted by $0.01 \mathrm{M} \mathrm{CaCl}_{2}$ solution in both the contaminated (control) and compost (C) rice husk biochar (RHB), cashew nut shell biochar (CNSB) and compost modified biochars (RHBC and CNSBC) treated soils.

As can be observed, increase in amendments doses from 0.05 to $0.4 \mathrm{~g} / \mathrm{g}$ soil decreased the extractable $\mathrm{Pb}$ concentrations from $60 \mathrm{mg} / \mathrm{kg}$ in the control soil to non-detectable levels in the Compost, CNSB, Compostmodified biochars and to $0.55 \mathrm{mg} / \mathrm{kg}$ in the RHB treated soils.

\subsection{Effect of Treatments on Maize Plant Growth}

To evaluate the efficiency of the treatments on the stabilisation of $\mathrm{Pb}$ in the soil and bioavailability in plant, maize plants were grown for six weeks on the untreated and treated soils. It must be noted that although maize plant would not generally be considered as appropriate plant to evaluate treatment efficiency, it was used because it is a known lead accumulator [24]. This implies that if reduction in bioavailable Pb levels could be achieved with an accumulator through the application of the amendments on the contaminated soil, then it will possibly be better with other plants and the remediation plan will be judged successful. The growth parameter, that is, plant height, number of leaves and leaf area for the plants grown on the control and amended soils were measured and the results are presented in Figure 2.

Maize growth was enhanced by the amendments except with higher rate of CNSB. There are variations in the mean plant height, number of leaves and leaf area ranging from $40 \pm 11$ to $90 \pm 1 \mathrm{~cm}, 2 \pm 1$ to $8 \pm 1$ and $70 \pm 8$ to $280 \pm 11 \mathrm{~cm}^{2}$ respectively among the plants grown on the soils. From the results, evidence of stunted growth perhaps due to $\mathrm{Pb}$ toxicity and the acidic nature of the soil were observed with plants grown on the control soil and the soil treated with higher rates of CNSB.

Plants grown on the soil that was amended with higher rate of CNSB showed mean height of $40 \mathrm{~cm}$ compare with $50 \mathrm{~cm}$ in the control, 2 leaves compared with 3 leaves in the control and an area of $70 \mathrm{~cm}^{2}$ compared with $86 \mathrm{~cm}^{2}$ in the control. The condition did not improve with addition of compost at this rate.CNS biocharis acidic as shown in Table 1. This likely had negative effect on the growth of the plant. On the other hand, compost, RHB and compost-modified RHB thrived with the three rates. The plants grown on them displayed healthy outlook and taller height with higher number of leaves and leaf areas. Plant parameters performed better with mixture of compost and the biochars at lower rates of $50 \mathrm{~g} / 500 \mathrm{~g}$ soil than when the two biochars were used singly at very high rates of $200 \mathrm{~g} / 500 \mathrm{~g}$ soil. The reason for this observation may be due to the combined effect of CEC and alkalinity impacted on the soil by the compost-modified RHB. As can be observed in Table 1, compost had the highest CEC followed by RHB and then CNSB. Cation exchange capacity of the amendments reflected their potential nutrient holding capacity. The combining effects of nutrient holding capacities of compost and RHB on making the contaminated soil fertile yielded healthier plants.

\subsection{Effects of Treatments on Maize Plant Dry Biomass}

The response of maize plant in terms of root and shoot dry biomass is presented in Figure 3. In view of the 

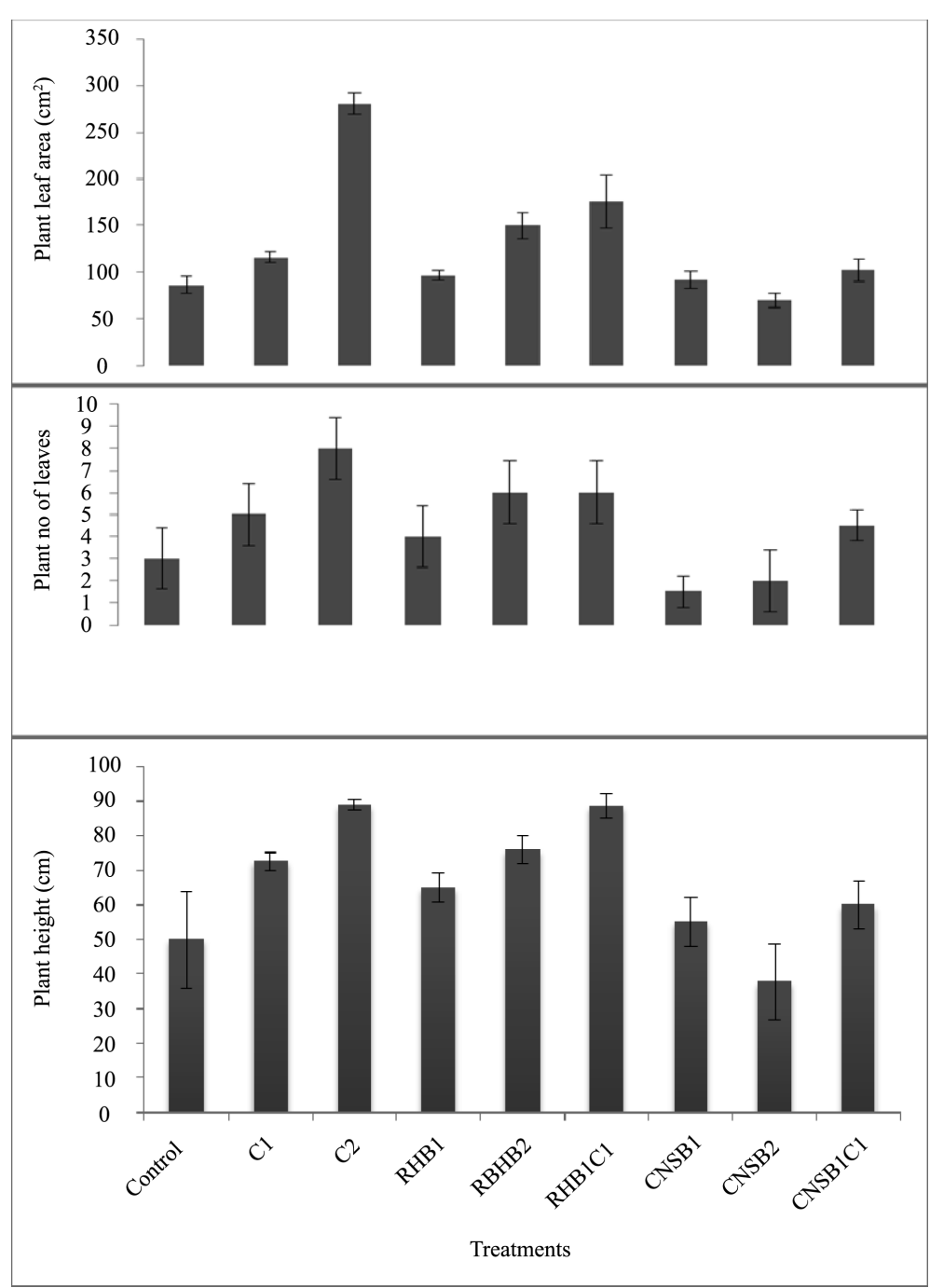

Figure 2. Growth parameters of maize plant grown for 6 weeks on lead contaminated (control) and compost (C) rice huskbiochar (RHB), cashew nut shell biochar (CNSB) and compost modified biochars (RHBC and CNSBC) treated soils. (a) Maize Plant leaf areas (b) maize plant number of leaves (c) maize plant height.

amendment type and rate, compost alone promoted the highest root and shoot biomass. For all other treatments, with the exception of CNSB at the rate of $200 \mathrm{~g} / 500 \mathrm{~g}$ the root and shoot biomass yields were higher than those of the control plant.

Cashew nut shell biochar at the highest rate $(200 \mathrm{~g} / 500 \mathrm{~g})$ produced the least root $(0.1)$ and shoot $(0.25)$ biomass values. However, addition of compost to the CNSB even at a lower rate (50 (1:1) g/500g) improved the performance of the biochar with 0.65 root and 1.45 shoot biomass values. The observed less performance of the CNSB may be associated with its acidic nature, the condition which is not favourable for plant growth. Unlike CNSB, the $\mathrm{pH}$ values of both compost (8.70) and RHB (7.40) are alkaline. The observed desirable performance of compost-modified CNSB may also be connected to this alkaline nature of compost which increased the $\mathrm{pH}$ of CNSB and therefore favours plant growth. This suggests that $\mathrm{pH}$ of the biochar is an important factor to consider when developing biochar remediation of heavy metals contaminated soils.

\subsection{Effects of Amendment on Post-Harvest Soil Pb Concentration}

The concentrations of $\mathrm{Pb}$ measured in soil, maize plant root and shoot after harvesting are shown in Table 2. 


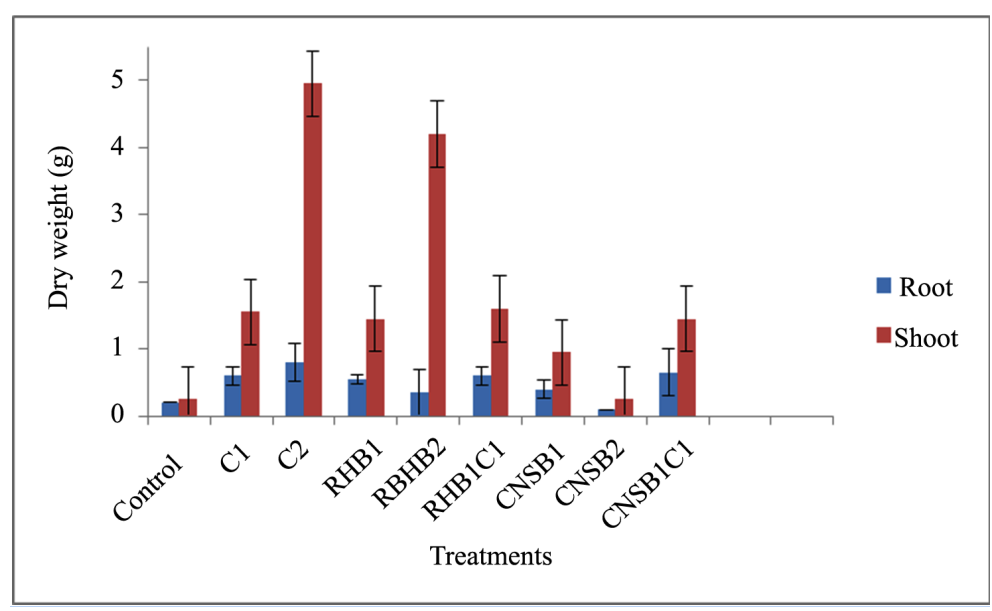

Figure 3 . Root and shoot mean \pm SD biomass values $(n=2)$ for maize plants grown on the contaminated soils (control), soil treated with compost (C1 $=25$ $\mathrm{g} / 500 \mathrm{~g}, \mathrm{C} 2=200 \mathrm{~g} / 500 \mathrm{~g}$ ), cashew nut shell biochar (CNSB), rice husk biochar (RHB) at $25 \mathrm{~g} / 500 \mathrm{~g}$ and $200 \mathrm{~g} / 500 \mathrm{~g}$ and compost modified biochars (RHBC and CNSBC) at $50 \mathrm{~g} / 500 \mathrm{~g}$ ( $25 \mathrm{~g} \mathrm{C}+25 \mathrm{~g}$ Biochars).

Table 2. Concentration of $\mathrm{Pb}(\mathrm{mg} / \mathrm{kg})$ measured in soil, maize plant root and shoot.

\begin{tabular}{cccc}
\hline Treatments & Post-Harvest Soil & Root & Shoot \\
\hline Control & 15,340 & 2260 & 530 \\
C1 & 8650 & 950 & 390 \\
C2 & 8250 & 650 & 210 \\
RHB1 & 12,200 & 410 & 120 \\
RHB2 & 9100 & 400 & 100 \\
RHB1/C1 & 9800 & 200 & 74 \\
CNSB1 & 12,750 & 500 & 140 \\
CNSB2 & 9950 & 450 & 190 \\
CNSB1/C1 & 10,600 & 260 & 100 \\
\hline
\end{tabular}

CNSB = Cashew nut shell biochar; RH B = Rice husk biochar; $\mathrm{C}=$ Compost.

Total soil $\mathrm{Pb}$ content was reduced from 15,340 mg/kg in the control soil after harvesting to concentrations which ranged from 8250 (C2) to 12,750 mg/kg (CNSB1) in the treated soils.

Similarly, total root $\mathrm{Pb}$ content was reduced from $2260 \mathrm{mg} / \mathrm{kg}$ to concentrations which ranged from 200 (RHB1/C1) to $950 \mathrm{mg} / \mathrm{kg}$ (C1). Furthermore, total shoot $\mathrm{Pb}$ content was reduced from $530 \mathrm{mg} / \mathrm{kg}$ to concentrations which ranged from 74 (RHB1/C1) to $390 \mathrm{mg} / \mathrm{kg}$ (C1). The results demonstrate that compost performed best in terms of stabilisation of $\mathrm{Pb}$ in soil while the compost-modified biochars particularly mixture of rice husk biochar and compost at lower rate performed better at reducing $\mathrm{Pb}$ available in maize plant. This was followed by the two biochars when used singly. The soil Pb levels in soil amended with higher rates $(200 \mathrm{~g} / 500 \mathrm{~g})$ of compost and amendments were the least. This perhaps was due to dilution effect which high rate of amendment could produce on the contaminant in soil [25]. However, this high application rate may not be applicable in real field conditions. Overall, application of compost-modified RHB performed best in terms of both stabilisation of $\mathrm{Pb}$ in soil and reduction in plant available $\mathrm{Pb}$.

The observed decrease in the concentration of $\mathrm{Pb}$ in the soil, plant root and shoot may be associated with some inherent factors of the different amendments which changed the chemistry of the soil. The factors among others include the $\mathrm{pH}$, organic matter and the chemical components of the amendments. 
Sabilisation of $\mathrm{Pb}$ in soil can be achieved through adsorption, complexation and precipitation which are influenced by the pH, dissolved organic carbon (humic substances) and mineral components of the amendments and soil respectively. At lower $\mathrm{pH}$ of the soil, there is an increase in the $\mathrm{H}^{+}$ion concentrations and it is expected that $\mathrm{H}^{+}$ion will compete with adsorption of $\mathrm{Pb}$ on the surface of the amended soil, thus decreasing stabilisation of $\mathrm{Pb}$ in the soil. At high $\mathrm{pH}, \mathrm{OH}^{-}$ion increases which favours soil stabilisation of $\mathrm{Pb}$. The acidic to near neutral $\mathrm{pH}(6.30)$ of CNSB coupled with acidity $(\mathrm{pH}=5.70)$ of the soil implies competition of $\mathrm{H}^{+}$with $\mathrm{Pb}$ on the surface of the CNSB amended soil, hence less $\mathrm{Pb}$ stabilisation. On the other hand, addition of compost and RHB to the soil was expected to increase the $\mathrm{pH}$ of the soil due to their alkaline $\mathrm{pH}$, implying an increase in the negative sites of the soil which favoured $\mathrm{Pb}$ stabilisation.

Compost and biochars contain dissolved organic matter (humic and fulvic acids) which also possibly enhanced stabilisation of $\mathrm{Pb}$ in soil. High ability of $\mathrm{Pb}$ to form more stable coordination complexes with humicacids has been documented [26]. Previously reported Fourier Transform Infrared(FTIR) studies on the organic constituents of compost and rice husk derived residues show that they contain organic functional groups such as alcohols, phenols, carboxylic acids and esters [27]-[29]. These functional groups would have become ionised at high $\mathrm{pH}$ and formed negatively charged ions which stabilized $\mathrm{Pb}$. The degree of stabilisation depends on the availability of the organic compounds in soil. Organic matter in biochars breaks down slowly to form dissolved organic matter (humic substances). This may explain the lower stabilisation of $\mathrm{Pb}$ in biochar amended soil when compared with compost amended soils. The release of dissolved organic matter in compost is faster due to the action of microorganisms, which implies higher concentrations in soil with more binding rates with soil $\mathrm{Pb}$. This probably accounts for enhanced $\mathrm{Pb}$ stabilsation in compost amended soil (Table 2).

Inorganic chemical composition of the amendments perhaps also played a important role in the stabilisation of $\mathrm{Pb}$ in the soil and uptake by plant. As presented in Table 1, compost had a high phosphorus content. Phosphorus reacts with $\mathrm{Pb}$ in soil to form pyromorphite $\left[\mathrm{Pb}_{5}\left(\mathrm{PO}_{4}\right)_{3} \mathrm{OH}\right]$, the most stable compound of $\mathrm{Pb}$ in the environment [30]. Xu et al. [28] identified peaks that were associated with $\mathrm{CO}_{3}^{2-}$ and $\mathrm{PO}_{4}^{3-}$ in FTIR spectra of Rice huskderived biochar. This suggests that stabilisation of $\mathrm{Pb}$ through precipitation of lead as carbonate and phosphate is a possibility. Typical XRF chemical characterisation of $\mathrm{RH}$ ash revealed that it contains up to $92 \% \mathrm{SiO}_{2}$ [31]. The result of this study also showed that RHB contained a high amount $(9780 \mathrm{mg} / \mathrm{kg})$ of Ca (Table 1). In a study by Wu et al. [27], XRD pattern of rice husk-derived biochar also indicates the presence of inorganic components such as $\mathrm{CaCO}_{3}, \mathrm{KCl}$ and $\mathrm{SiO}_{2}$. Following these obtained and documented results, $\mathrm{Pb}$ stablisation in the RHB amended soils may also be attributed to encapsulation of $\mathrm{Pb}$ in the calcium silicate hydrate $(\mathrm{C}-\mathrm{S}-\mathrm{H})$ gel formed from the pozzolanic reaction of Ca with the silica content of RHB in an alkaline environment of the soil [32]. Thus, this prevented $\mathrm{Pb}$ from becoming available in compost-RHB amended soil. Nevertheless, further investigations are required to justify or reject these assumptions.

\subsection{Effect of Treatments on Uptake of Pb by Maize Plant}

The results of uptake of $\mathrm{Pb}$ in maize plant grown both on the control and amended soils are shown in Table 2. The root and shoot $\mathrm{Pb}$ concentrations in the untreated soil were substantially higher than those in the treated soils. In the plants that were grown on the control soil, Pb concentrations of 2260 and $530 \mathrm{mg} / \mathrm{kg}$ were observed in the root and shoot respectively. All the amendments reduced maize plant Pb uptake, although to different extents. The least $\mathrm{Pb}$ uptake by maize was observed in the soil treated with compost-modified RHB followed by compost-modified CNSB, RH-biochar, CNS-biochar and then compost. Compost-modified RH-Biochar at the rates of $50 \mathrm{~g} / 500 \mathrm{~g}$ soil lowered the root concentrations by $91 \%$. Similarly, it reduced the shoot $\mathrm{Pb}$ from 530 $\mathrm{mg} / \mathrm{kg}$ to 74 (86.0\%). The results suggest that compost-modified biochars performed better than the amendments being used singly. It is interesting to note that stabilisation of $\mathrm{Pb}$ in soil amended with compost is better than stabilisation of $\mathrm{Pb}$ in biochar amended soils. However, uptake by plant is higher in compost treated soils. This may be attributed to higher humic substances (humic and fulvic acids) contained in the compost. Fulvic acids (FAs) are smaller than humic acids (HAs) and are more chemically reactive than HAs. Due to their smaller size, they can enter plant roots and shoots readily thereby carrying along heavy metals. As cited by Boruvka and Drabek [26], heavy metals bound on insoluble humic substances are relatively immobile. On the other hand, binding on smaller organic molecules may increase metal mobility and bioavailability. Considering the results of this pot experiments, it can be deduced that remediation of $\mathrm{Pb}$ contaminated soil with compost-modified biochar has great potential to reduce bioavailable $\mathrm{Pb}$. 


\section{Conclusion}

The physico-chemical parameters of compost, rice husk biochar and to an extent cashew nut shell biochar present them as non-toxic, potential soil fertilisers and heavy metal immobilising agents. There are substantial observable reductions in extractable $\mathrm{Pb}$ concentrations in $\mathrm{Pb}$ smelting slag contaminated soil, maize plant root and shoot following the application of compost, rice husk and cashew nut shell biochars and compost-modified biochars. The combined effects of nutrient holding capacities of compost and RHB on making the contaminated soil fertile yield healthier plants. The extent of stabilisation might have been controlled by $\mathrm{pH}$, organic matter and the chemical components of the amendments. Application of compost was the best in lowering $\mathrm{Pb}$ in soil while compost-modified RH-biochar was the best in lowering uptake by maize plant. Cashew nut shell performed less both in stabilsation of $\mathrm{Pb}$ in soil and plant uptake especially when applied singly. The observed less performance of the CNSB may be associated with its acidic nature, the condition which is unfavourable to plant growth. This suggests that the $\mathrm{pH}$ of biochar is an important factor to consider when developing biochar remediation of heavy metals contaminated soils. Combination of compost with biochar could be a very effective way of decontaminating and re-vegetating lead smelting slag-contaminated soil. There is a need for further studies on optimisation of the use of compost modified-biochar in the contaminated soil, its effects on other minor quantities of heavy metals that may be contained in the soil, its mechanism of heavy metals stabilization in soil and field applications.

\section{References}

[1] Zeng, L.-S., Liao, M., Chen, C.-L. and Huang, C.-Y. (2006) Effects of Lead Contamination on Soilmicrobial Activity and Rice Physiological Indices in Soil-Pb-Rice (Oryza sativa L.) System. Chemosphere, 65, 567-574. http://dx.doi.org/10.1016/j.chemosphere.2006.02.039

[2] Agency for Toxic Substances and Disease Registry (2005) Toxicological Profile for Lead. US Department of Health and Human Services. Public Health Service, Agency for Toxic Substances and Disease Registry Division of Toxicology and Environmental Medicine/Applied Toxicology Branch 600 Clifton Road NE, Mailstop F 32, Atlanta, Georgia 30333.

[3] de Andrade Lima, L.R.P. and Bernardez, L.A. (2011) Characterization of the Lead Smelter Slag in Santo Amaro, Bahia, Brazil. Journal of Hazardous Materials, 189, 692-699. http://dx.doi.org/10.1016/j.jhazmat.2011.02.091

[4] Yang, Y., Li, S., Bi, X., Wu, Y., Liu, T., Li, F. and Liu, C. (2010) Lead, Zn, and Cd in Slags, Stream Sediments and Soils in an Abandoned Zn Smelting Region, Southwest of China, and $\mathrm{Pb}$ and S Isotopes as Source Tracers. Journal of Soils \& Sediments, 10, 1527-1539. http://dx.doi.org/10.1007/s11368-010-0253-z

[5] Ogundiran, M.B. and Osibanjo, O. (2009) Mobility and Speciation of Heavy Metals in Soils Impacted by Hazardous Waste. Chemical Speciation \&Bioavailability, 21, 59-69.

[6] Swords, C. and Strange, J. (2006) Active Containment System for a Former Industrial Site in East London. Engineering Geology, 85, 204-211. http://dx.doi.org/10.1016/j.enggeo.2005.09.040

[7] Ogundiran, M.B. and Osibanjo, O. (2009b) Effects of Phosphate Chemicals Treatments on Auto Battery Waste Contaminated Soil in Nigeria. Journal of Solid Waste Technology \& Management, 35, 181-190. http://dx.doi.org/10.5276/JSWTM.2009.181

[8] Farrell, M. and Jones, D.L. (2010) Use of Composts in the Remediation of Heavy Metal Contaminated Soil. Journal of Hazardous Material, 175, 575-582. http://dx.doi.org/10.1016/j.jhazmat.2009.10.044

[9] Adejumo, S.A., Togun, A.O., Adediran, J.A. and Ogundiran, M.B. (2011) Field Assessment of Progressive Remediation of Soil Contaminated with Lead-Acid Battery Waste in Response to Compost Application. Pedologist, 54, 182193.

[10] Fleming, M., Tai, Y., Zhuang, P. and McBride, M.M. (2013) Extractability and Bioavailability of Pb and As in Historically Contaminated Orchard Soil: Effects of Compost Amendments. Environmental Pollution, 177, 90-97. http://dx.doi.org/10.1016/j.envpol.2013.02.013

[11] Tang, J., Zhu, W., Kookana, R. and Katayama, A. (2013) Characteristics of Biochar and Its Application in Remediation of Contaminated Soil. Journal of Bioscience and Bioengineering, 116, 653-659. http://dx.doi.org/10.1016/j.jbiosc.2013.05.035

[12] Beesley, L., Moreno-Jimenez, E., Gomez-Eyles, J.L., Harris, E., Robinson, B. and Sizmur, T. (2011) A Review of Biochars' Potential Role in the Remediation, Revegetation and Restoration of Contaminated Soils. Environmental Pollution, 159, 3269-3282. http://dx.doi.org/10.1016/j.envpol.2011.07.023

[13] Jiang, J., Xu, R.-K., Jiang, T.-Y. and Li, Z. (2012) Immobilization of Cu(II), Pb(II) and Cd(II) by the Addition of Rice 
Straw Derived Biochar to a Simulated Polluted Ultisol. Journal of Hazardous Materials, 229-230, 145-150. http://dx.doi.org/10.1016/j.jhazmat.2012.05.086

[14] Herath, I., Kumarathilaka, P., Navaratne, A., Rajakaruna, N. and Vithanage, M. (2015) Immobilization and Phytotoxicity Reduction of Heavy Metals in Serpentine Soil Using Biochar. Journal of Soils \& Sediments, 15, 126-138. http://dx.doi.org/10.1007/s11368-014-0967-4

[15] Carrier, M., Hardie, A.G., Uras, U., Gorgens, J. and Knoetze J. (2012) Production of Char from Vacuum Pyrolysis of South-African Sugar Cane Bagasse and Its Characterization as Activated Carbon and Biochar. Journal of Analytical \& Applied Pyrolysis, 96, 24-32. http://dx.doi.org/10.1016/j.jaap.2012.02.016

[16] Günther, F. (2007) Simple Biochar Production Method: A Two-Barrel Charcoal. http://www.holon.se/folke

[17] Walkley, A. and Black, A.I. (1934) An Examination of the Degtjareff Method for Determining Soil Organic Matter and a Proposed Modification of the Chromium Acid Titration Method. Soil Science, 37, 29-38. http://dx.doi.org/10.1097/00010694-193401000-00003

[18] Ogundiran, M.B. and Osibanjo, O. (2008) Heavy Metal Concentrations in Soils and Accumulation in Plants Growing in a Deserted Slag Dumpsite in Nigeria. African Journal of Biotechnology, 7, 3053-3060.

[19] Pleysier, J.L. and Juo, A.S.R. (1980) A Single Extraction Method Using Silver Thiourea for Measuring Exchangeable Cations and Effective CEC in Soils with Variable Charges. Soil Science, 129, 205-211. http://dx.doi.org/10.1097/00010694-198004000-00002

[20] Shuman, L.M. (1990) Comparison of Exchangeable Al, Extractable Al in Soil Fractions. Canadian Journal of Soil Science, 70, 263-275. http://dx.doi.org/10.4141/cjss90-028

[21] ISO 11261 (2005) Determination of Kjeldahl Nitrogen in Soil, Biowaste and Sewage Sludge.

[22] Mehlich, A. (1984) Mehlich 3 Soil Test Extractant: A Modification of Mehlich 2 Extractant. Communications in Soil Science \& Plant Analysis, 15, 1409-1416. http://dx.doi.org/10.1080/00103628409367568

[23] Trevisan, M.T.S., Pfundstein, B., Haubner, R., Wurtele, G., Spiegelhalder, B., Bartsch, H. and Owen, R.W. (2006) Characterization of Alkyl Phenols in Cashew (Anacardium occidentale) Products and Assay of Their Antioxidant Capacity. Food Chemistry \& Toxicology, 44, 188-197. http://dx.doi.org/10.1016/j.fct.2005.06.012

[24] Salati, S., Quadri, G., Tambone, F. and Adani, F. (2010) Fresh Organic Matter of Municipal Solid Waste Enhances Phytoextraction of Heavy Metals from Contaminated Soil. Environmental Pollution, 158, 1899-1906. http://dx.doi.org/10.1016/j.envpol.2009.10.039

[25] Gonzalez-Nunez, R., Alba, M.D., Orta, M.M., Vidal, M. and Rigol, A. (2012) Remediation of Metal-Contaminated Soils with the Addition of Materials-Part II: Leaching Tests to Evaluate the Efficiency of Materials in the Remediation of Contaminated Soils. Chemosphere, 87, 829-837. http://dx.doi.org/10.1016/j.chemosphere.2012.01.015

[26] Boruvka, L. and Drabek, O. (2004) Heavy Metal Distribution between Fractions of Humic Substances in Heavily Polluted Soils. Plant Soil \& Environment, 50, 339-345.

[27] Wu, W., Yang, M., Feng, O., McGrouther, K., Wang, H., Lu, H. and Chen, Y. (2012) Chemical Characterization of Rice Straw-Derived Biochar for Soil Amendment. Biomass and Bioenergy, 47, 268-276. http://dx.doi.org/10.1016/j.biombioe.2012.09.034

[28] Xu, X., Cao, X. and Zhao, L. (2013) Comparison of Rice Husk- and Dairy Manure-Derived Biochars for Simultaneously Removing Heavy Metals from Aqueous Solutions: Role of Mineral Components in Biochars. Chemosphere, 92, 955-961. http://dx.doi.org/10.1016/j.chemosphere.2013.03.009

[29] Zmora-Nahum, S., Hadar, Y. and Chen, Y. (2007) Physico-Chemical Properties of Commercial Composts Varying in Their Source Materials and Country of Origin. Soil Biology \& Biochemistry, 39, 1263-1276. http://dx.doi.org/10.1016/j.soilbio.2006.12.017

[30] Ma, Q.Y., Traina, S.J. and Logan, T.J. (1995) Lead Immobilization from Aqueous Solutions and Contaminated Soils Using Phosphate Rocks. Environmental Science \& Technology, 29, 1118-1126. http://dx.doi.org/10.1021/es00004a034

[31] Rukzon, S., Chindaprasirt, P. and Mahachai, R. (2009) Effect of Grinding on Chemical and Physical Properties of Rice Husk Ash. International Journal of Minerals, Metallurgy \& Materials, 16, 242-247. http://dx.doi.org/10.1016/S1674-4799(09)60041-8

[32] Bade, R., Oh, S. and Shin, W.S. (2012) Assessment of Metal Bioavailability in Smelter-Contaminated Soil before and after Lime Amendment. Ecotoxicology \& Environmental Safety, 80, 299-307. http://dx.doi.org/10.1016/j.ecoenv.2012.03.019 